\title{
層状化合物半導体の作製と評価
}

\author{
伊 藤 浩 ${ }^{\mathrm{a},{ }^{*}}$ \\ a 東京工業高等専門学校 電気工学科 ( ₹ 193-0997 東京都八王子市椚田町 1220-2)
}

\section{Film Growth and Characterization of Layered Compound Semiconductor}

\section{Hiroshi ITO ${ }^{\text {a }}$}

\begin{abstract}
${ }^{a}$ Department of Electrical Engineering, National College of Technology (1220-2, Kunugida-cyo, Hachiouji-shi, Tokyo 193-0997)
\end{abstract}
Keywords : Gallium Telluride, layered semiconductor, thin film, glass substrate

\section{1. 諸言}

III - VI族化合物半導体の GaSe, GaS や GaTe などは層状構 造を示し，層内は共有結合で，層間はファン・デル・ワール ス力で結合した 2 次元的結晶物質である。そのため, 層状半 導体とも呼ばれ, 電気的特性や光学的特性に強く異方性を示 し, 古くから研究が行われている ${ }^{1), 2)}$ 。この層状半導体の

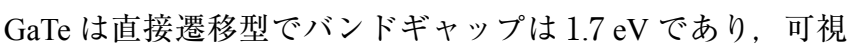
光の波長領域であることから, 光学デバイスへの応用に注目 されている。また, 層状半導体は結晶成長において, 結合力 の弱いファン・デル・ワールス面で成長することが報告され ており，異種基板上で比較的容易に結晶成長し，へテロエピ タキシー技術への応用も期待されている ${ }^{3)}$ 。そこで，本研究 では電子ビーム蒸着装置を用い, 層状化合物半導体 GaTe の ガラス基板上結晶性薄膜を作製し，GaTe 薄膜の結晶性，膜 構造, 膜組成および，光学特性について評価検討した。

\section{2. 実験方法}

$\mathrm{GaTe}$ 薄膜の作製には，電子ビーム蒸着装置を用いた。蒸 着母材には, 純度 99.999\%の塊状 GaTe 結晶 (高純度科学研 究所製)を用い, 粉砕してからタブレット状に加工した。基 板温度は室温から $500{ }^{\circ} \mathrm{C}$ まで変化させた。基板には, 前処理 としてアセトンおよび, 純水による超音波洗浄で処理した Corrning\#7059 ガラスを用い, 成膜時の蒸発速度および蒸発 量は水晶振動子膜厚計より一定とした。薄膜の結晶性評価に はXRD (BrukerAXS 製，D8 ADVANCE，線源：CuK $\alpha$ )，表 面観察には FE-SEM (FEI 製, Quanta250FEG)，組成分析には XPS (ULVAC-PHI 製, Model5600), 光学特性の評価には可視 紫外分光光度計 (Hitachi 製, U-3400)を用いた。

\section{3．結果および考察}

\section{3. $1 \mathrm{GaTe}$ 薄膜の結晶構造}

図 1 に基板温度を変化させて得られた $\mathrm{GaTe}$ 薄膜の XRD

\footnotetext{
*E-mail : h-ito@tokyo-ct.ac.jp
}

スペクトルを示す。図1の結果から，基板温度が室温から $400{ }^{\circ} \mathrm{C}$ までは結晶性を示す回折ピークは見られず，非晶質膜 であることがわかる。基板温度が $500{ }^{\circ} \mathrm{C} て ゙ は(200)$ 面，（400） 面の回折ピークが現れ, 結晶化している。この回折面から $\mathrm{GaTe}$ 結晶の $a$ 軸が基板面に対して垂直に配向していること がわかる。GaTe 結晶構造は単斜晶系であるから, ファン・ デル・ワールス結合面が斜めに配向していることになる。他 の層状半導体 $\mathrm{GaSe}$ や $\mathrm{GaS}$ とは配向性が異なる ${ }^{4)}$ 。

図 2 に膜厚をパラメータとして GaTe 薄膜の XRD スペク トルを示す。膜厚に依存して (004) 面の回折ピーク強度が高 くなっており, 結晶性が向上していることが考えられる。こ のことから, 膜成長初期の薄い場合には, 非晶質のガラス基 板界面で膜構造が乱れ結晶性が低くなり，膜成長とともに構 造の乱れが緩和され，結晶性が向上したものと考えられる。 すなわち, 膜厚 $430 \mathrm{~nm}$ 程度で, 結晶性の高い $\mathrm{GaTe}$ 薄膜が 作製できると考えられる。

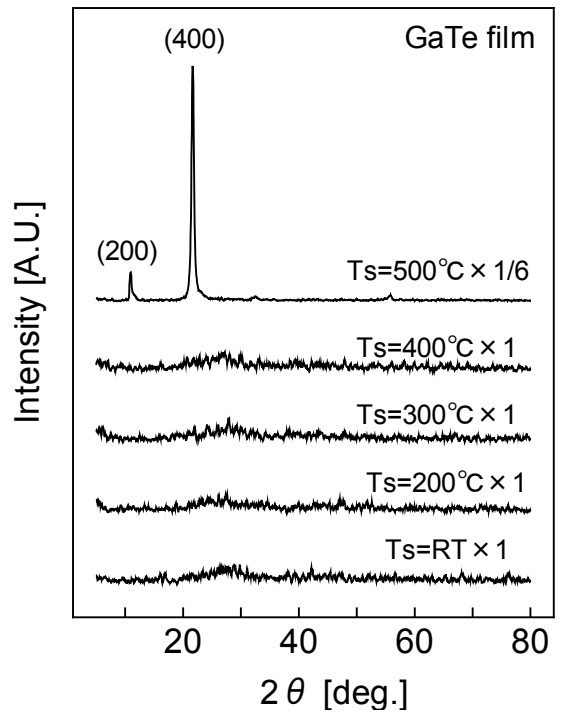

Fig. 1 XRD spectra of GaTe films on the glass substrate at various substrate temperature. 


\section{2 表面観察}

図 3 に FE-SEM で観察した GaTe 薄膜の表面構造を示す。 基板温度が室温の試料では, 粒径 $300 \mathrm{~nm}$ 程度の粒成長がみ られるが， $200{ }^{\circ} \mathrm{C}$ 以上の試料では存在せず平坦である。また， すべての温度の試料表面に数十 $\mathrm{nm}$ 程度の細かい粒が見られ るが，これは SEM 観察用にコーティングした PtPd 膜の影響 と考えている。結晶性の高い $500{ }^{\circ} \mathrm{C}$ の試料では, 結晶配向性 から表面凹凸が大きくなると考えられるが，本研究の観察範 囲内では非常に平坦な表面構造である。

\section{3. $3 \mathrm{GaTe}$ 薄膜の組成分析}

図 4 にXPS による GaTe 薄膜の XPS 組成分析結果を示す。 図には，比較のために加圧整形した蒸着母材 Bulk (A) と加 工前 Bulk (B)の分析結果も示している。 GaTe 薄膜では, $\mathrm{Te} /$ $\mathrm{Ga}$ 比が化学量論比と大きく異なり, 酸素も多く存在している。 加工後の Bulk (A) と比較すると, ほぼ同等の組成となって いるが, 加工前の Bulk（B)では酸素は存在せず，化学量論 比に近い組成である。よって, GaTe 薄膜中の酸素は成膜䨌 囲気から混入したものではなく，母材の加工中に大気から混

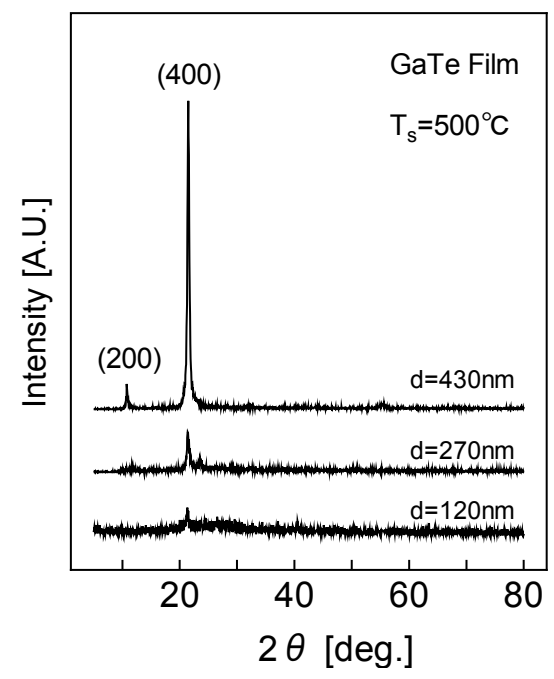

Fig. 2 XRD spectra of GaTe films on the glass substrate as a function of film thickness.
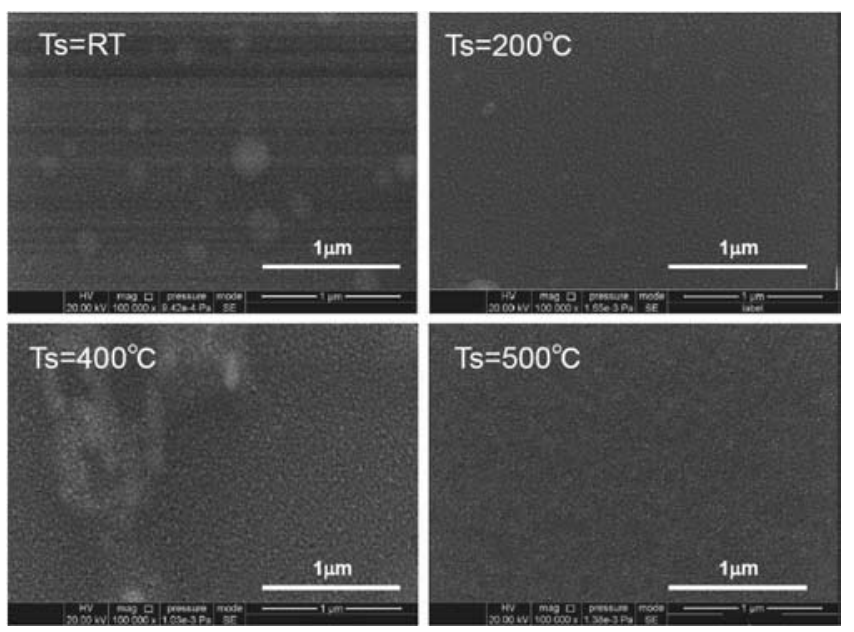

Fig. 3 FE-SEM images of GaTe films on the glass substrate varied the substrate temperature.
入した酸素に由来するといえる。薄膜中の $\mathrm{O}$ は $\mathrm{Ga}$ か $\mathrm{Te}$ と 酸化物を形成していると考えられるが，薄膜の組成比から $\mathrm{O}$ の多くは Ga と結合していると推察する。これらのことから， 得られた薄膜は多結晶 $\mathrm{GaTe}$ 領域と, 酸化ガリウム $(\mathrm{GaO})$ 領 域とが混在した薄膜である。

\section{4 光吸収特性}

図 5 に GaTe 薄膜の光吸収特性を示す。この結果では膜厚 の効果を検討するために, 光エネルギー $(h v)$ が $2.0 \mathrm{eV}$ 付近 で吸収特性が一致するようプロットしている。膜厚が $270 \mathrm{~nm}$ の特性では, 光学エネルギーが $3 \mathrm{eV}$ 以上で $120 \mathrm{~nm}$ の特性と異なる特性が現れる。また, 膜厚が $430 \mathrm{~nm}$ では $2.5 \mathrm{eV}$ 以上で同様に膜厚が $270 \mathrm{~nm}$ の傾きと異なる特性が現 れている。図2の結晶性評価の結果より, 膜厚にともない結 晶性が向上したことから，図 5 の光吸収特性に現れる変化は, $\mathrm{GaTe}$ 結晶の光吸収量に依存した変化と考えられる。よって, 膜厚の厚い $430 \mathrm{~nm}$ では $240 \mathrm{~nm}$ よりも低エネルギー側の $2.5 \mathrm{eV}$ 付近から $\mathrm{GaTe}$ 結晶の光吸収特性を示していると考え ている。

\section{4. 結言}

本研究では, 電子ビーム蒸着法を用い, ガラス基板上に

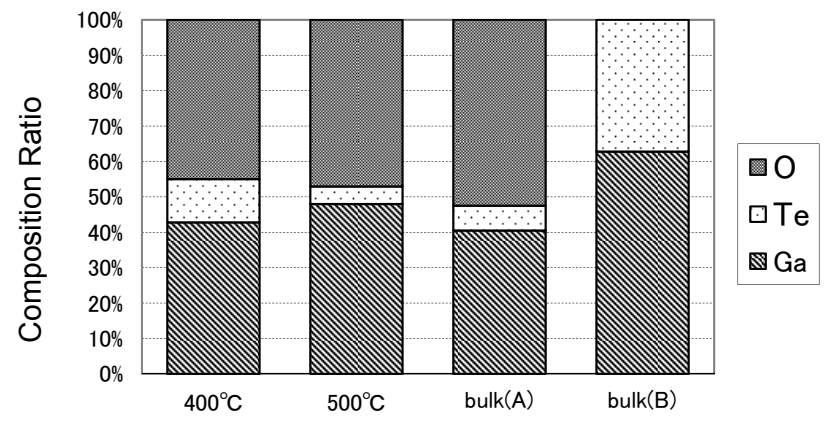

Fig. 4 Results of composition analysis of GaTe films and bulk crystals. In this figure, the label "bulk (A)" indicates the mother material after the film deposition and the label "bulk (B)" indicates the mother material before that.

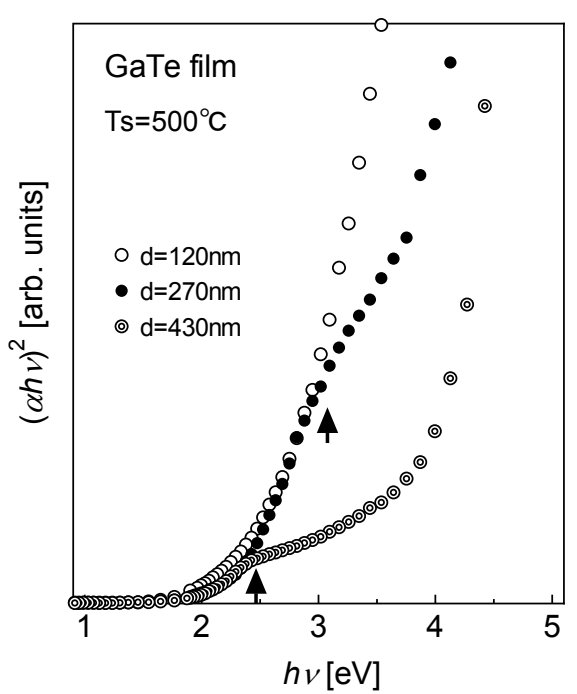

Fig. 5 Photoabsorption characteristics of GaTe films on the glass substrate as a function of film thickness. 
GaTe 化合物半導体の結晶化薄膜を作製し, 基板温度および 膜厚をパラメータに, 結晶性, 膜構造, 膜組成および, 光学 特性の評価検討を行った。基板温度 $500{ }^{\circ} \mathrm{C}$, 膜厚 $430 \mathrm{~nm}$ で 成膜した $\mathrm{GaTe}$ 薄膜は, 結晶性が高く, 平坦な表面構造である。 また，得られた GaTe 薄膜はXPS の結果より, GaTe と GaO が混在した薄膜であり, 光吸収特性に 2 つの基礎吸収端を示 す特性が現れることがわかった。

(Received May 2, 2012 ; Accepted May 18, 2012)

\section{文献}

1 ) M. Shimada, S. Sugano ; J. Phys. Soc. Japan, 21, 1936 (1966).

2 ) U. Giorgianni, G. Mondio, P. Perillo, G. Saitta, G. Vermiglio ; J. Phys., 38, 1293 (1977).

3 ) A. Koma, K. Sunouchi, T. Miyajima ; J. Vac. Sci. Technol., B3, 724 (1985).

4 ) W. B. Pearson ; Acta Crystallogr., 17, 1 (1964). 